\title{
Declining returns to investment in tertiary education in Vietnam
}

\section{Ngoc Thi Minh Tran*}

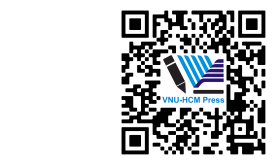

Use your smartphone to scan this QR code and download this article

\begin{abstract}
The human capital theory in economics argues that education is an investment in human capital and that the acquisition of knowledge and skills would enable individuals to increase their productivity and earnings, and thereby contributing to economic growth. As an investment, education incurs costs and benefits at various points in time. To measure economic benefits of education investment by individuals, economists use the rate of return to investment in education. This rate of return should be positive and higher than that of alternative options to ensure economic benefits of education investment and motivate education decisions. Given that tertiary education attainment is costly to individuals and the society at large, highly positive returns to tertiary education matter for individual and social human capital investments being economically justified. In the present age of mass access to tertiary education, the pattern of declining returns to investment in tertiary education was observed in a growing number of countries that include Vietnam. This trend may avert individual investment in human capital formation, and thereby negatively affecting national economic growth and development. To contribute to addressing this problem, the current paper aims to analyse the factors that drive the decay in returns to investment in tertiary education in Vietnam. Based on the descriptive research method using descriptive statistics, we summarize key trends in tertiary education in Vietnam. We identify that the abatement in returns to tertiary education investment in Vietnam may be attributed to three main factors: (i) the expansion of education supply, in particular tertiary education; (ii) the economic downturn after the global financial crisis; and (iii) the mismatched quality of tertiary education. These findings are foundations for our suggestions on possible solutions to inform the tertiary education development strategy.

Key words: returns to education investment, declining, tertiary education, Vietnam
\end{abstract}

Department of Economics, University of Economics and Law, Vietnam National University, Ho Chi Minh City, Vietnam

\section{Correspondence}

Ngoc Thi Minh Tran, Department of Economics, University of Economics and Law, Vietnam National University, Ho Chi Minh City, Vietnam

Email: ngocttm@uel.edu.vn

History

- Received: 26/2/2020

- Accepted: 7/7/2020

- Published: 16/8/2020

DOI : 10.32508/stdjelm.v4i3.590

\section{Check for updates}

\section{Copyright}

(c) VNU-HCM Press. This is an openaccess article distributed under the terms of the Creative Commons Attribution 4.0 International license.

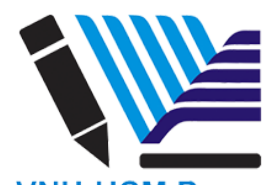

VNU-HCM Press

\section{INTRODUCTION}

The rate of return to investment in education is important to evaluate the effectiveness of human capital investments. Given that tertiary education attainment is costly to individuals and the society at large, highly positive returns to tertiary education matter for individual and social human capital investments being economically justified. Extant empirical evidence has been showing that the benefits of tertiary education accrue to both tertiary-graduated individuals and the economy as a whole ${ }^{1}$. At the individual level, tertiary graduates are more likely to have better labour market outcomes in terms of employment and earnings than adults without tertiary qualifications. At the economy level, the pool of tertiary graduates enlarges government tax revenues and contributes to economic growth and development through the generation of technology. However, in the present age of mass access to tertiary education ${ }^{2}$, the pattern of falling returns to investment in tertiary education was observed in a growing number of countries ${ }^{3-5}$ that include Vietnam ${ }^{6}$. Vietnam experienced a rapid increase in returns to education in the 1990s and 2000s.
Yet, the increasing pattern appeared to have turned around since the global financial crisis in 2008. This trend may avert investment in human capital formation, and thereby negatively affect economic growth and development. To contribute to addressing this problem, the current paper aims to analyse the factors that drive the fall in returns to investment in tertiary education in Vietnam and suggest possible solutions to inform the tertiary education development strategy.

To achieve these objectives, this paper employs the descriptive research method using descriptive statistics. By means of analyzing data calculated by the Institute for Statistics of the United Nations Educational, Scientific and Cultural Organization (UNESCO) and the Department of Statistics of the International Labour Organization (ILO), as well as data from the ILO's Labour Force Surveys, we present key trends in tertiary education in Vietnam. We argue that the abatement in returns to tertiary education investment in Vietnam may be attributed to three main factors: (i) the expansion of education supply, in particular tertiary education; (ii) the economic downturn after the 
global financial crisis; and (iii) the mismatched quality of tertiary education.

The remainder of this paper is organized as follows. The next section introduces key definitions and the human capital theory. After that follows a brief summary of recent trends in tertiary education in Vietnam. The subsequent section analyses the causes of the abatement in returns to investment in tertiary education in Vietnam. The final section concludes with recommendations.

\section{LITERATURE REVIEW}

The two key concepts used in the current paper include tertiary education and the rate of return to investment in education. According to the definition of UNESCO [ $\left.{ }^{7}, \mathrm{p} 83\right]$, "tertiary education builds on secondary education, providing learning activities in specialised fields of education." More specifically, tertiary education commonly refers to all postsecondary education, including academic education at universities and colleges, and advanced vocational or professional education at technical training institutes and vocational schools. Post-secondary education in the education system of Vietnam includes universities and colleges. ${ }^{\text {a }}$ Therefore, this paper uses tertiary education and post-secondary education interchangeably to indicate academic education at universities and colleges.

The concept of the rate of return to investment in education has emerged from the human capital theory in economics formulated in the early 1960s by Becker ${ }^{8,9}$. The human capital theory argues that education is an investment in human capital and that the acquisition of knowledge and skills would enable individuals to increase their productivity and earnings, and thereby contributing to economic growth. As an investment, education incurs costs and benefits at various points in time. To measure economic benefits of education investment by individuals, economists use the rate of return to investment in education, which "equates the value of lifetime earnings of the individual to the net present value of costs of education" [ $\left.{ }^{10}, \mathrm{p} 446\right]$. This rate of return should be positive and higher than that of alternative investments to ensure economic benefits of education investment and motivate education decisions.

This paper is built on the human capital theory by Becker ${ }^{8,9}$, focusing on the returns to investment in tertiary education along the dimensions of employment and income of tertiary graduates. Theoretically, tertiary education attainment relates to better

\footnotetext{
ahttps://wenr.wes.org/2017/11/education-in-vietnam
}

labour market outcomes in terms of employment and wage premium. Available data and extant empirical research in economics ${ }^{11-13}$ attest the human capital theory in the context of Vietnam. However, recent economic estimations for the post global financial crisis period revealed decreasing returns to tertiary education investment in Vietnam ${ }^{6}$. To provide a broad picture, in the next section we briefly summarize recent trends in tertiary education in Vietnam.

\section{Recent trends in tertiary education in Viet- nam}

Since the economic reform in 1986, Vietnam has become a rapidly growing and dynamic country with an average annual GDP growth rate of 6.1 percent over the last ten years. To maintain and boost economic growth, the Vietnamese government has been prioritizing education, especially tertiary education. In terms of demographics, Vietnam has a large population size of 96 million people as reported in Census 2019, and a quarter of the population is under the age of 15 . With a relatively young and economically active population, Vietnam has a remarkable number of students entering tertiary education every year. As presented in Figure 1, tertiary education enrolment in Vietnam has been amplifying significantly since the mid-1990s. The absolute volume of enrolment reached nearly 2.7 million students in 2014, accounting for 31 percent of the total population of the fiveyear age group following on from secondary school leaving (i.e. the gross tertiary enrolment ratio). However, a retrogressing trend was observed in 2015 and 2016, with 8.4 percent and 6.5 percent of reduction in tertiary education participation in each respective year. The total tertiary education enrolment was 2.3 million students in 2016, pulling the gross tertiary enrolment ratio down to 26 percent.

Figure 2 depicts one of the key indicators of the labour market by ILO, i.e. the employment-to-population ratio by education attainment in the period 2015-2018. This ratio is defined as the proportion of a country's working-age population that is employed. As demonstrated in Figure 2, tertiary education attainment is more likely to increase the chance of employment among graduates. More specifically, tertiary graduates had the highest employment-to-population ratio measured as the percentage of the number of persons who are employed to the total working age population. In 2018, more than 85 percent of those people who completed either the first or the second stage of tertiary education ${ }^{\mathrm{b}}$ were employed.

\footnotetext{
${ }^{\mathrm{b}}$ The first stage of tertiary education does not lead directly to an advanced research qualification. The second stage of tertiary education leads to an advanced research qualification.
} 


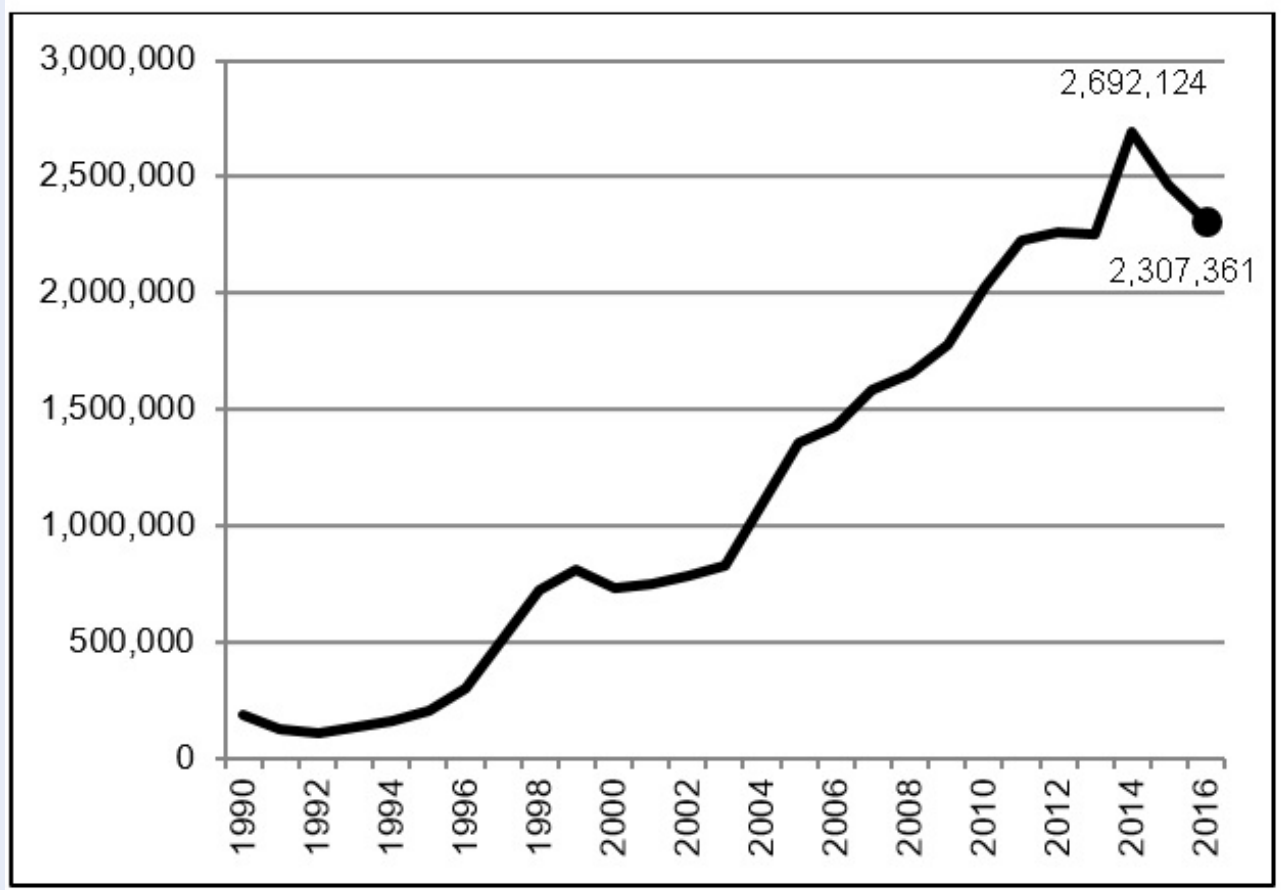

Figure 1: Number of students enrolled in tertiary education institutions in Vietnam, 1990-2016 (Data source: The UNESCO Institute for Statistics ${ }^{a}$ 0pthttp://uis.unesco.org/ )

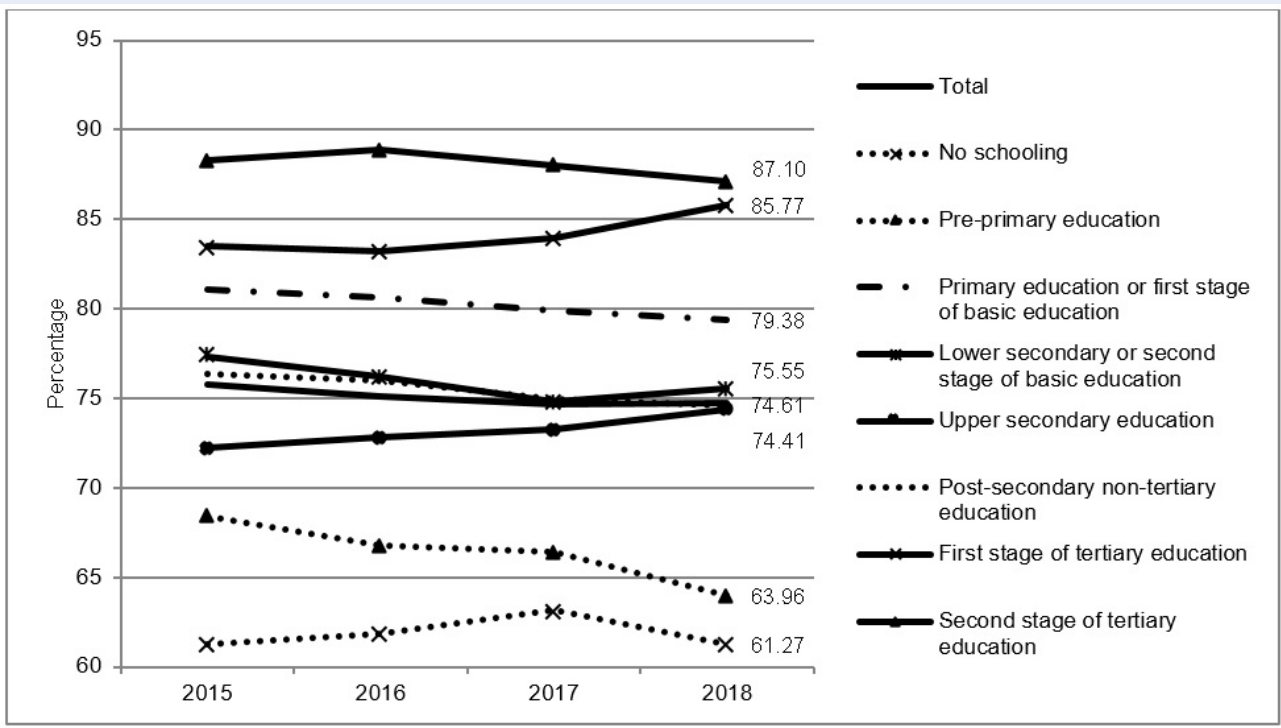

Figure 2: Employment-to-population ratio by education attainment in Vietnam, 2015-2018 (Data source: The ILO Department of Statistics ${ }^{a}$ Opthttps://ilostat.ilo.org/data/ ) 
Tertiary education attainment also brings about wage premium for graduates. Figure 3 displays the variation in average monthly employment income of wageworkers measured in thousand Vietnam Dong by education attainment in the period 2010-2016. An education-level comparison of employment income reveals a substantial wage premium for individuals with university or higher qualifications. Moreover, the differential on employment income between wage workers with university or higher qualifications and those people with professional secondary qualifications was around 1.5 times throughout the period 2010-2016.

Drawing from these statistics, tertiary education attainment relates to better labour market outcomes in terms of employment and wage premium. Economists' analytical research also provided empirical evidence on increasing returns to education in Vietnam. Gallup ${ }^{11}$ found an increase in the returns to schooling between 1993 and 1998, while Liu ${ }^{12}$ reported increasing returns to tertiary education during the same period of time. Oostendrop and Doan ${ }^{13}$ and Doan et al. ${ }^{6}$ found similar results for the period 1998-2006 and the period 1998-2008, respectively. Nonetheless, Doan et al. ${ }^{6}$ 's estimations also revealed decreasing returns to tertiary education investment in Vietnam between 2008 and 2014. This empirical evidence may explain the worsening trend of tertiary education enrolment displayed in Figure 1.

\section{Causes of the declining returns to invest- ment in tertiary education in Vietnam}

The abatement in returns to tertiary education investment in Vietnam observed in the recent empirical estimations may be attributed to three main factors, including (i) the expansion of education supply, in particular tertiary education, (ii) the economic downturn after the global financial crisis, and (iii) the mismatched quality of tertiary education.

\section{The expansion of education supply, in par- ticular higher education}

The economic transition process from a centrally planned to a market-based economy in Vietnam since 1986 and the country's efforts put into international integration have fundamentally changed the Vietnamese labour market. The creation of a private sector labour market with the participation of domestic and foreign enterprises has remarkably amplified sources of employment. Moreover, the needs to remain and achieve further economic growth in the era of accelerated technological progress have placed immense de- mand for highly skilled labour. The surge in the demand for highly skilled workers in the 1990s effectuated abundant employment opportunities and competitive earnings for individuals with tertiary qualifications. Consequently, acquiring tertiary qualifications has long been believed to be the gospel of a successful youth transition to employment in the Vietnamese society. Accessing tertiary education became one of the prioritized goals of Vietnamese youth and their parents.

The substantial request for highly skilled labour and the social demand for tertiary education access drove the expansion in the education system of Vietnam in both scale and scope. According to the statistics of the Ministry of Education and Training (MOET), Vietnam had 235 universities, 60 colleges, and 74,991 lecturers with various academic qualifications by 2018 . The expansion in the number of tertiary education providers and the massive enrolment in tertiary education have increased the supply of labour with tertiary qualifications. On average, there were around 300,000 tertiary graduates joining the pool of job seekers every year. This quantity of annual supply of tertiary graduates quickly surpassed the demand of the market for highly skilled labour, resulting in an oversupply of labour with tertiary qualifications. The oversupply would definitely lead to a deterioration of the returns to education investment, i.e. lower wage rate and higher unemployment rate among those graduates. Figure 4 presents unemployment rates by education attainment in Vietnam from 2015 to 2018. This figure shows that people with bachelor degrees (or the first stage of tertiary education) have the highest unemployment rate among the labour force.

\section{The economic downturn after the global fi- nancial crisis}

The decay in the returns to tertiary education investment not only originated from the oversupply in the labour market but also stemmed from the shrunk demand for labour caused by the economic downturn after the global financial crisis. The impressive economic performance of Vietnam effectuated by the restructuring process has decelerated in recent years, especially after the global financial crisis. This economic stagnation could be attributed to poor economic governance of the government and the spill-over effects of the crisis. After more than three decades of economic reform, Vietnam still has made only trivial moves toward decentralization and privatization. Centralization in economic governance and the favoured stateconglomerate model, which was criticized for poor efficiency and corruption, have weakened the national 


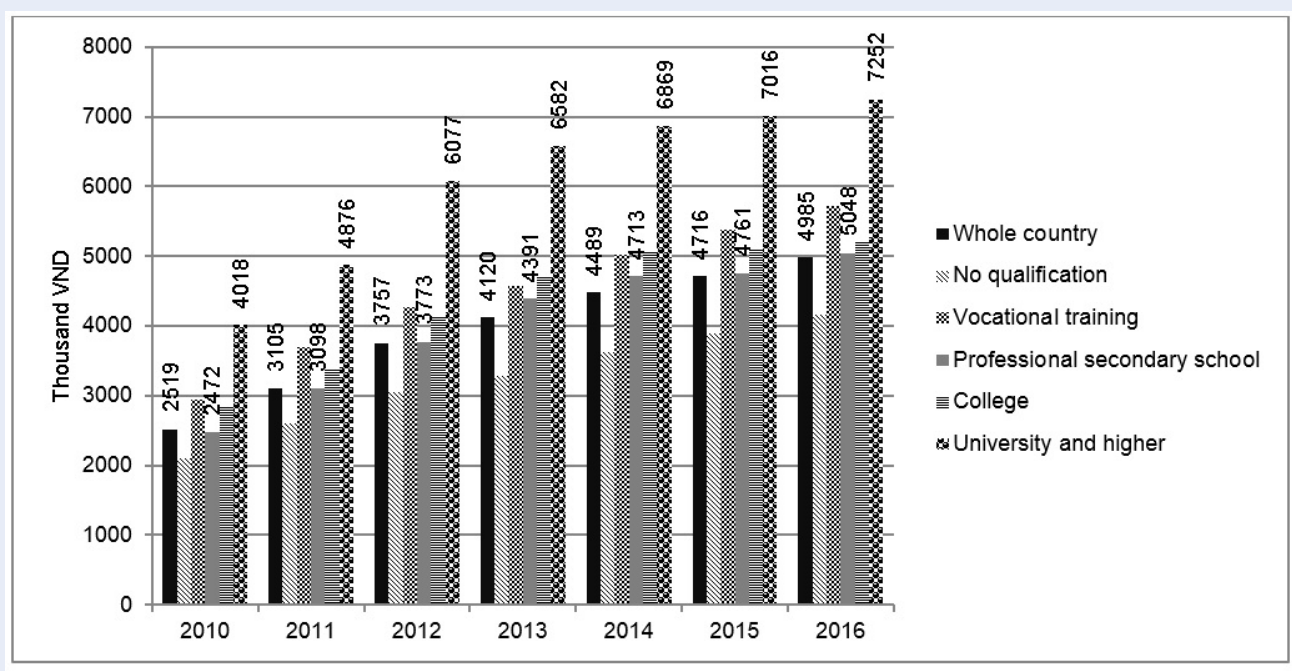

Figure 3: Average monthly employment income of wage workers by education attainment in Vietnam, 2010-2016 (Data source: ILO's Labour Force Survey $2016^{a} 0$ pthttps://www.ilo.org/surveyLib/index.php/catalog/1837 )

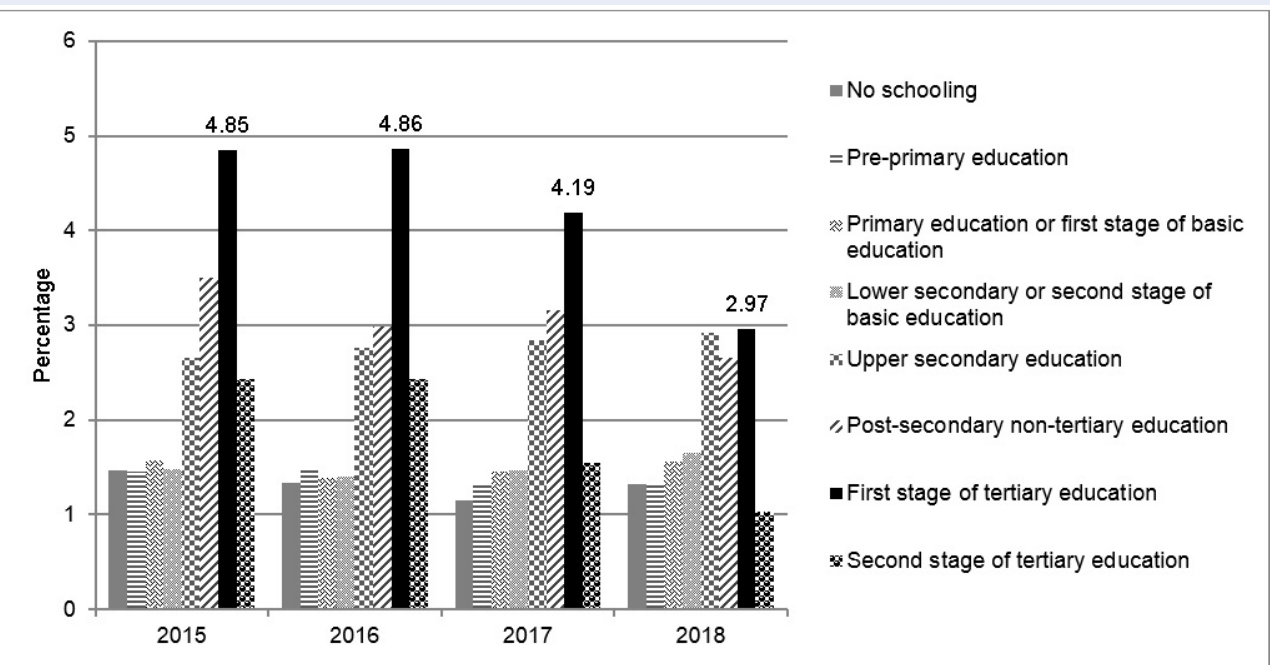

Figure 4: Unemployment rates by education attainment in Vietnam, 2015-2018 (Data source: The ILO Department of Statistics ${ }^{a}$ Opthttps://ilostat.ilo.org/data/ ) 
resources for economic growth and development. In addition to the internal poor economic governance, the external shock brought by the global financial crisis forced the economy to experience low aggregate demand, production contraction, high inflation, government budget deficit, high unemployment rate, and economic recession. Such an economic contractionary situation would not allow the labour market to be able to absorb the substantial quantity of labour supply, especially the supply of tertiary graduates, or pay high wage rates.

\section{The mismatched quality of tertiary educa- tion}

Tertiary education in Vietnam demonstrated an unbalanced expansion, which was biased toward the scale rather than the quality of education per $\mathrm{se}^{14}$. The quality of tertiary training in Vietnam has not always matched the expansion in tertiary education in terms of the number of providers and the substantial intakes of tertiary students during the second half of the 2000s. The pressure of achieving the targeted number of new enrolments coerced tertiary education providers into lowering admission requirements. Furthermore, tertiary education institutions in Vietnam have to respond to the top down pressure from the MOET in terms of achieving high graduation rates and high employment rates of graduates. These administrative orders inevitably would result in a permissiveness in maintaining and improving the quality of teaching and learning, and superfluous, or even inflated, statistics of employment rates of graduates reported by tertiary education providers. The required statistics are more likely to be flawed for lacking the information of employment distribution across various occupations in society. Hence, many universities and colleges would not aim to provide students with knowledge and skills that are necessary for their professional development upon graduation. The falling of standards within universities and colleges has made tertiary education attainment fail to signal the respective skill level of graduates. As a result, a larger proportion of tertiary education graduates have been struggling to obtain jobs that match their academic qualifications. Given the popular presence of ridehailing companies in Vietnam offering services that include peer-to-peer ridesharing, ride service hailing, and food delivery, accepting a job as a rider for the ride-hailing companies has become a possible resort for many job seekers with tertiary qualifications in Vietnam.

\section{CONCLUSIONS AND RECOMMENDATIONS}

The current paper summarizes recent trends in tertiary education in Vietnam and focuses on the falling returns to investment in tertiary education. This trend is worth warning because it would discourage investment in tertiary education by individuals, and thereby reducing the share of highly skilled workers in the labour force. In the era of technological advance, a shortage of highly skilled workers would steer the country away from the industrialization and modernization goals, and hamper economic growth and development.

Three factors are identified to drive the declining trend: (i) the oversupply of job seekers with tertiary qualifications as a result of the expansion in both scale and scope of tertiary education, (ii) the decreased demand for labour that followed the economic downturn in the late 2000s, and (iii) the unwholesome development of tertiary education characterized by falling standards within universities and colleges. While the first two factors are at the macro level and given, the third factor is within the control of universities and colleges. Based on the nature of these factors, possible solutions to the issue are presented below.

First, at the national policy level, the government should make evidence-based policies for tertiary education development. A factor that plays an important role in making evidence-based policies is data. Given that the statistics reported by universities and colleges are flawed, the MOET should use more reliable statistics on employment rates of graduates to inform the tertiary education development strategy. A national survey on employment and earnings at the transition of youth to work would collect rich and reliable data for the purpose.

Second, standards within universities and colleges should be improved significantly. Tertiary education admission requirements should ensure the selection of qualified candidates for the training process to become highly skilled workers. Universities and colleges should improve the quality of teaching and learning per se and provide students with knowledge and skills needed by themselves and the society as argued by Bobbitt ${ }^{15}$, rather than chasing economic benefits of universities and colleges or superfluously responding to top down pressure from the government.

Third and finally, practical consultation for students during their transition from high-schools to a later stage in life is very necessary. Students who are preparing for graduation from high-schools need to 
understand their strengths, weaknesses, and job expectations in order to make a informed choice upon leaving high-schools. Students and parents also need to realise the illusion that tertiary education is the only way to ensure prosperity for youth. Therefore, transition programs designed for high-school students and their parents would be a useful forum to discuss different paths to a successful future for youth.

In general, there may be other factors that can explain the fall in returns to tertiary education investment in Vietnam. In my viewpoint, an investigation into the curricula developed in a centrally planned education system should be an interesting area for future research on this topic.

\section{LIST OF ABBREVIATIONS}

ILO: The International Labour Organization MOET: The Ministry of Education and Training UNESCO: The United Nations Educational, Scientific and Cultural Organization

\section{CONFLICTS OF INTEREST}

The author declares that she has no conflicts of interest.

\section{AUTHORS' CONTRIBUTIONS}

Tran Thi Minh Ngoc has done all works of the article as a sole author.

\section{REFERENCES}

1. OECD. Education at a Glance 2019: OECD Indicators. Paris: OECD Publishing. 2019;.

2. Murray $C$. Too many people are going to college. In: Flinders DJ, Thornton SJ, editors. The curriculum studies reader. 5th ed. New York and London: Routledge. 2017;

3. Bennell P. Rates of return to education: Does the conventional pattern prevail in sub-Saharan Africa? . World Development.
1996;24(1):183-199. Available from: https://doi.org/10.1016/ 0305-750X(95)00115-S.

4. Gonzalez N, Oyelere RU. Are returns to education on the decline in Venezuela and does Mission Sucre have a role to play? Economics of Education Review. 2011;30(6):1348-1369. Available from: https://doi.org/10.1016/j.econedurev.2011.07.007.

5. Purnastuti L, Miller PW, Salim R. Declining rates of return to education: evidence for Indonesia. Bulletin of Indonesian Economic Studies. 2013;49(2):213-236. Available from: https: //doi.org/10.1080/00074918.2013.809842.

6. Doan T, Le Q, Tran TQ. Lost in Transition? Declining Returns to Education in Vietnam. The European Journal of Development Research. 2018;30(2):195-216. Available from: https://doi.org/ 10.1057/s41287-017-0080-9.

7. UNESCO. International Standard Classification of Education. Montreal: UNESCO Institute for Statistics. 2012;

8. Becker GS. Investment in Human Capital: A Theoretical Analysis. Journal of Political Economy. 1962;70(5):9-49. Available from: https://doi.org/10.1086/258724.

9. Becker GS. Human Capital: A Theoretical and Empirical Analysis, with Special Reference to Education. 1st ed. Chicago: University of Chicago Press for the National Bureau of Economic Research. 1964;

10. Psacharopoulos G, Patrinos HA. Returns to investment in education: a decennial review of the global literature. Education Economics. 2018;26(5):445-458. Available from: https: //doi.org/10.1080/09645292.2018.1484426.

11. Gallup JL. The wage labor market and inequality in Viet Nam in the 1990s. The World Bank. 2002;2896. Available from: https: //doi.org/10.1596/1813-9450-2896.

12. Liu AYC. Changing wage structure and education in Vietnam, 1992-98. Economics of Transition and Institutional Change. 2006;14(4):681-706. Available from: https://doi.org/10.1111/j. 1468-0351.2006.00266.x.

13. Oostendorp RH, Doan $\mathrm{QH}$. Have the returns to education really increased in Vietnam? Wage versus employment effect. Journal of Comparative Economics. 2013;41(3):923-938. Available from: https://doi.org/10.1016/j.jce.2012.12.002.

14. Bodewig C, Badiani-Magnusson R, Macdonald K, Newhouse $D$, Rutkowski J. Skilling up Vietnam: Preparing the workforce for a modern market economy. Washington, DC: World Bank. 2014;07. Available from: https://doi.org/10.1596/978-1-46480231-7.

15. Bobbitt F. Scientific method in curriculum-making. In: Flinders DJ, Thornton SJ, editors. The curriculum studies reader. 5th ed. New York and London: Routledge. 2017;. 


\section{Suất sinh lợi từ đầu tư cho giáo dục đại học giảm ở Việt Nam}

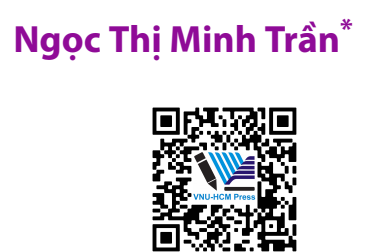

Use your smartphone to scan this QR code and download this article
Khoa Kinh tế, Trường Đại học Kinh tế Luật, ĐHQG-HCM, Việt Nam

\section{Liên hệ}

Ngọc Thị Minh Trần, Khoa Kinh tế, Trường Đại học Kinh tế - Luật, ĐHQG-HCM, Việt Nam Email: ngocttm@uel.edu.vn

Lịch sử

- Ngày nhận: 26/2/2020

- Ngày chấp nhận: 7/7/2020

- Ngày đăng: 16/8/2020

DOI : 10.32508/stdjelm.v4i3.590

\section{Check for updates}

\section{Bản quyền}

๑ Đ ĐHQG Tp.HCM. Đây là bài báo công bố mở được phát hành theo các điều khoản của the Creative Commons Attribution 4.0 International license.

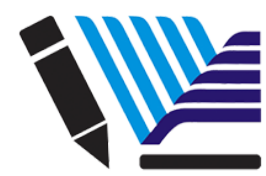

VNU-HCM Press

\section{TÓM TẮT}

Lý thuyết vốn con người trong kinh tế học xem giáo dục là một hình thức đầu tư vào vốn con người và việc trang bị kiến thức cùng kỹ năng sẽ giúp cá nhân nâng cao năng suất và thu nhập, góp phần cho tăng trưởng kinh tế. Do là đâuu tư nên giáo dục mang lại lọi ích cũng như chi phí tại nhiều thời điểm. Để đo lường lợi ích kinh tế của việc cá nhân đầu tư cho giáo dục, các kinh tế gia sử dụng suất sinh lợi từ đầu tư cho giáo dục. Suất sinh lợi này cần phải dương và cao hơn suất sinh lợi của các lựa chọn đầu tư khác nhằm đảm bảo lợi ích kinh tế khi đầu tư cho giáo dục và thúc đẳy các quyết định liên quan đến giáo dục. Do việc theo đuổi giáo dục đại học rất tốn kém đối với cá nhân và xã hội, nên suất sinh lợi cao đóng vai trò quan trọng trong lựa chọn đầu tư cho vốn con người của cá nhân và xã hội. Trong bối cảnh đại chúng tiếp cận với giáo dục đại học, suất sinh lợi từ đầu tu cho giáo dục đại học có xu hướng giảm ở nhiều quốc gia, trong đó có Việt Nam. Xu hướng này có thể cản trở đầu tư của cá nhân vào việc hình thành vốn con người, và kéo theo tác động tiêu cực lên tăng trưởng và phát triển kinh tế quốc gia. Nhằm góp phần giải quyết vấn đề nêu trên, bài báo này phân tích các nguyên nhân dẫn đến sự suy giảm suất sinh lợi từ đầu tư cho giáo dục đại học ở Việt Nam. Bằng phương pháp thống kê mô tả, chúng tôi tóm tắt các xu hướng gần đây của giáo dục đại học ở Việt Nam. Chúng tôi xác định ba nguyên nhân của sự suy giảm suất sinh lợi từ đầu tư cho giáo dục đại học ở Việt Nam, gồm: (i) tình trạng gia tăng cung giáo dục, đặc biệt là giáo dục đại học; (ii) tình hình kinh tế suy thoái sau cuộc khủng hoảng tài chính toàn cầu; và (iii) chất lượng giáo dục đại học không đáp ứng được yêu cầu của xã hội. Những phát hiện này là cơ sở để chúng tôi đề xuất các giải pháp làm chất liệu cho chiến lược phát triển giáo dục đại học

Từ khoá: suất sinh lợi từ đầu tư cho giáo dục, suy giảm, giáo dục đại học, Việt Nam
Trích dẫn bài báo này: Trần N T M. Suất sinh lợi từ đầu tư cho giáo dục đại học giảm ở Việt Nam. Sci. Tech. Dev. J. - Eco. Law Manag.; 4(3):851-858. 